McGill Law Journal — Revue de droit de McGill

\title{
In PRAise OF JUs COGENS' CONCEPTUAL INCOHERENCE
}

\author{
Jens David Ohlin*
}

* Vice Dean and Professor of Law, Cornell Law School.

(C) Jens David Ohlin 2018

Citation: (2018) 63:4 McGill LJ 1 — Référence : (2018) 63:4 RD McGill 1 


\section{Introduction}

I. From Natural Law to Legal Positivism

II. The Positivization of Natural Law

III. The Fiduciary Theory of Jus Cogens

IV. The Value of Obfuscation

\section{Conclusion}




\section{Introduction}

One of the virtues of Evan Criddle's and Evan Fox-Decent's Fiduciaries of Humanity is that it offers a compelling theoretical account of one longtroubled concept, jus cogens - that part of international law that is obligatory, non-derogable, and which prevails over any other inconsistent legal obligations. ${ }^{1}$ Typically, international lawyers agree that the category of $j u s$ cogens exists but cannot agree on its conceptual foundation, or better yet, refuse entirely to address the question of its origins. ${ }^{2}$ The fiduciary theory holds that state sovereignty is both justified by, and limited by, the fiduciary obligations of the state itself. ${ }^{3}$ The state acts as a fiduciary-and must therefore act in the interests of-two groups, one internal to the state and the other external to it. ${ }^{4}$ The first group, the internal one, is the people of the state, thus establishing that the state has fiduciary obligations towards its own citizens. ${ }^{5}$ The second group, the external one, is humanity at large, thus establishing that the state has fiduciary obligations to other states and foreigners, obligations that can require the state to respect not only the human rights of foreigners but also the requirements of international law in state-to-state relations. ${ }^{6}$ This dual-fiduciary relationship provides not only a conceptual grounding for state sovereignty but also explains the limits of state sovereignty. In a sense, the fiduciary theory excavates the inner workings of sovereignty and shows it to represent a "deal" conferred on the state by the international community. States are provided a domaine réservé to control their own territory and their own people, but in exercising that control must act in the interests of their own people and humanity at large.

The fiduciary theory helps explain how and why international law can impose mandatory and non-derogable obligations on the state-obligations

1 For a general discussion of jus cogens, see Ian Brownlie, Principles of Public International Law, 7th ed (Oxford: Oxford University Press, 2008) 510-12.

2 See e.g. Pamela J Stephens, "A Categorical Approach to Human Rights Claims: Jus Cogens as a Limitation on Enforcement?" (2004) 22:2 Wis Intl LJ 245 ("[t]here is little agreement about the source of jus cogens norms: where do they come from; how are new ones formed?" at 249).

3 See generally Evan J Criddle \& Evan Fox-Decent, Fiduciaries of Humanity: How International Law Constitutes Authority (New York: Oxford University Press, 2016) [Criddle \& Fox-Decent, Fiduciaries of Humanity].

4 Ibid at 30 (describing states as "joint fiduciaries of humanity").

$5 \quad$ Ibid at 13 ("the relational character of state sovereignty is best understood as a fiduciary relationship between a state and the nationals and non-nationals amenable to its jurisdiction").

$6 \quad$ Ibid at 171 ("states do not owe fiduciary duties solely to their own people; in a variety of respects, international law also enlists states as co-fiduciaries for humanity generally with responsibility to create and maintain an international legal order in which all human beings may enjoy secure and equal freedom"). 
(2018) 63:4 MCGIll LaW JOURNAL — REVUE DE DroIT DE MCGILL

that did not flow from the consent of the state through voluntary agreements, such as treaties. ${ }^{7}$ Under the fiduciary theory, the category of jus cogens obligations represent the non-derogable conditions of sovereignty that a state owes jointly to its own citizens and to humanity at large. In short, a fiduciary theory provides what international lawyers have long been searching for-a compelling analytical foundation for a category of legal norms that practitioners consider invaluable but which theoreticians find perplexing. Although prior theoretical accounts of jus cogens have come and gone, each was implausible for a variety of reasons, or raised more questions than it answered. ${ }^{8}$ So, it would seem that we should herald the fiduciary theory for its ability to answer these thorny questions.

However, in recognizing the sophistication of the fiduciary theory and praising its account of jus cogens, we should avoid the temptation to decry the lengthy conceptual confusion that has come before it. Although conceptual coherence is usually laudatory, in this case, the opposite is true: the failure to recognize the true nature of jus cogens is precisely what allowed the concept to flourish spectacularly over the last half century, thus allowing the human rights revolution to succeed. ${ }^{9}$ International law has been, and continues to be, dominated by legal positivism, the idea that the rules constituting international law flow from particular sources of law such as treaties or customary international law, and that these sources provide the content of international law regardless of their moral or ethical content. ${ }^{10}$ To identify the content of international legal norms, one can consult these "positive" sources without the need for any deeper ethical or moral investigation. In the case of treaties, one need only ask whether the document was executed and ratified in the appropriate way so as to create a binding legal obligation. In the case of custom, one need only ask whether the custom is backed by the sufficient state practice performed under a sense of legal obligation, or opinio juris, to qualify as law under the rubric of customary international law. The content of international law is provided by these positive sources without reference to whether these rules are morally or ethically good or not.

$7 \quad$ Ibid at 78 ("the fiduciary model offers a persuasive and unified account of IHRL and jus cogens because it brings them together within a relational concept of sovereignty that treats states ... as fiduciaries of the people amenable to their jurisdiction").

8 See infra notes 36-41 and accompanying text.

9 See Myres S McDougal, Harold D Lasswell \& Lung-chu Chen, Human Rights and World Public Order: The Basic Policies of an International Law of Human Dignity (New Haven: Yale University Press, 1980) at 345.

10 See Martin V Totaro, "Legal Positivism, Constructivism, and International Human Rights Law: The Case of Participatory Development" (2008) 48:4 Va J Intl L 719 (noting that "[l]egal rules in the international realm arise through treaties, custom, and general principles of international law, although the last two categories are particularly contested" at 724). 
The category of legal norms carrying the label "jus cogens" complicates international law's commitment to legal positivism and a theory of sources built around treaties and custom. ${ }^{11}$ One of the implications of jus cogens is that some legal norms are obligatory, so that even a treaty that is formally valid-say because it was executed and ratified in the appropriate manner-would be null and void if its content transgressed the demands of $j u s$ cogens. ${ }^{12}$ For this reason, jus cogens and legal positivism stand in marked tension, so much so that a committed legal positivist - which most international lawyers are —ought to be extremely skeptical that jus cogens norms exist at all. To support and apply jus cogens, one should, ideally, have an answer to where jus cogens comes from-and it ought to be something more compelling than deus ex machina.

From the perspective of the international lawyer who believes that jus cogens is an essential tool in the toolbox of his or her legal categories, it is perhaps a good thing that the conceptual foundation of jus cogens was not scrutinized more closely in the twentieth century when jus cogens norms were coming to prominence and playing a central role in the human rights revolution in the second half of that century. Had these debates played out explicitly, international lawyers may very well have rejected jus cogens on account of its failure to comply with the demands of the strict legal positivism that reigned during that era, and in many ways continues to hold sway among international lawyers today. This conclusion is deeply counter-intuitive-because it suggests that conceptual confusion is a good thing-but the conclusion is a function of the particular role that a positivistic theory of sources plays within the general structure of international law and the tension between jus cogens and that dominant theory of sources.

Because lawyers were unable to craft a simple answer that explained how jus cogens could be consistent with the dominant theory of the sources of international law, jus cogens has labored in a state of conceptual confusion for decades. But paradoxically, if all of these tensions had been resolved decades ago, the result might have been that lawyers reaffirmed a

11 See A Mark Weisburd, "The Emptiness of the Concept of Jus Cogens, as Illustrated by the War in Bosnia-Herzegovina" (1995) 17:1 Mich J Intl L 1 (concluding that when "scholars cannot agree as to whether jus cogens norms are to be derived from positive law or are, instead, emanations of natural law, there is reason to question whether there is even a core understanding of the concept" at 28).

12 For example, the Vienna Convention states that:

A treaty is void if, at the time of its conclusion, it conflicts with a peremptory norm of general international law. For the purposes of the present Convention, a peremptory norm of general international law is a norm accepted and recognized by the international community of States as a whole as a norm from which no derogation is permitted and which can be modified only by a subsequent norm of general international law having the same character.

Vienna Convention on the Law of Treaties, 23 May 1969, 1155 UNTS 331, art 53 (entered into force 27 January 1980). 
traditional theory of sources but rejected the emerging notion of jus cogens because of its perceived lack of fidelity to the dominant theory of sources. The conceptual confusion prevented international lawyers from having to make this stark choice, and instead, allowed them to retain the traditional theory of sources and embrace the new conceptual category of jus cogens, despite the tensions. If the tensions had been spelled out, this would not have been possible.

This Essay tells the story of this conceptual confusion and evaluates the fiduciary theory - and its new solution to the riddle of jus cogens - against that general background. Part I argues that the most compelling account of jus cogens is that it flows from natural law and constitutes the "ethically minimum" content of international law. ${ }^{13}$ A natural law theory holds that the content of law is provided, at least partially, by facts about the nature of humanity and the nature of the world, including principles of reason and morality. ${ }^{14}$ Although natural law was once considered an acceptable and obvious approach to jurisprudence, its significance waned at the expense of legal positivism. ${ }^{15}$ However, the hierarchical quality of jus cogens is best explained by some element of natural law-and its explicit invocation of moral content-rather than anything one might find in legal positivism.

Part II describes how this natural law conception of jus cogens was then sublimated in a way palatable for the current demands of legal positivism. Part III focuses on the fiduciary theory and explains how the fiduciary theory provides a compelling account of jus cogens. However, Part III also defends the proposition that the fiduciary theory is inherently naturalistic, in the sense that what is doing the heavy lifting in its conceptual enterprise is something that lays beyond the positive sources of international law and is therefore, at least partially, a naturalistic enterprise, even if it would be unfashionable in today's parlance to describe the fiduciary theory as an exercise in natural law theory. The best description of it would be partially neo-naturalistic.

Finally, Part IV evaluates the obfuscation created by international lawyers' persistent refusal to recognize the latent naturalism within jus cogens. While rueful from the point of view of legal theory, the obfuscation was nonetheless essential for jus cogens to succeed in its stealth attack. If, in an alternate world, jus cogens was viewed, transparently and accurately, as a vestige of natural law, modern international lawyers would never have accepted it, or at the very least would not have accepted it to the degree

13 There are a few international legal scholars who support a natural law-inspired interpretation of jus cogens. See e.g. Mark W Janis, "Jus Cogens: An Artful Not a Scientific Reality" (1988) 3:2 Conn J Intl L. 370.

14 See generally Mark C Murphy, Natural Law in Jurisprudence and Politics (New York: Cambridge University Press, 2006).

15 Ibid at $20 \mathrm{ff}$. 
that they have. Part IV then responds to the objection that the failure to recognize the natural law origins of jus cogens hampered its development because there was no agreed upon standard for identifying which legal norms counted as jus cogens or not. In response, I concede the point but make two quick responses. First, no account of jus cogens offers compelling, unambiguous criteria, and second, the lack of clarity on its criteria was a good price to pay in exchange for the legal category's widespread adoption. In other words, in a world where the natural law criteria for jus cogens were adequately communicated they would not have been widely shared by the members of the invisible college of international lawyers, whose preference for legal positivism was even stronger than their desire for an ethical minimum. In the end, the notion that jus cogens is consistent with international law's legal positivism was a useful fiction, a "noble lie" that gave us modern human rights law.

\section{From Natural Law to Legal Positivism}

International law was once hospitable to natural law, but no more. ${ }^{16}$ Today, international lawyers insist on rigorous adherence to positive sources of law: treaties, custom, general principles of domestic law and, in accordance with article 38 of the International Court of Justice (ICJ) Statute, scholarship and judicial decisions as subsidiary sources of law. ${ }^{17}$ Appealing to natural law as support for a proposition of law is not likely to constitute winning advocacy. International lawyers today consider natural law to be a subdiscipline of philosophy, not worthy of the label "law" in any meaningful sense. ${ }^{18}$

16 See L Oppenheim, "The Science of International Law: Its Task and Method" (1908) 2 Am J Intl L 313 (rejecting role for natural law in developing international law in the future at 327-30); Mary Ellen O'Connell \& Caleb Day, "Sources and the Legality and Validity of International Law: Natural Law as Source of Extra-Positive Norms" in Samantha Besson \& Jean D'Aspremont, eds, The Oxford Handbook of the Sources of International Law (Oxford: Oxford University Press, 2017) 562 (noting that despite its central place in the history of international law, natural law discussion "had nearly come to an end by the 1960s" at 563).

17 See Statute for the Permanent Court of International Justice, 16 December 1920, 6 LNTS 390 (entered into force 8 October 1921) [ICJ Statute]. But see Alain Pellet, "Article 38" in Andreas Zimmermann, Christian Tomuschat \& Karin Oellers-Frahm, eds, The Statute of the International Court of Justice: A Commentary (Oxford: Oxford University Press, 2006) 677, 700-701 (2006) (suggesting that the ICJ has sometimes resorted to other sources of international law and that the list in article 38 is "incomplete" and that "as time has passed, its lacunae have become more and more apparent" at 700-01 [emphasis in original]).

18 For a discussion of this evolution, see "Natural Law for Today's Lawyer" (1957) 9:3 Stan L Rev 455 (suggesting that "the natural law language disappeared from the courts, the opinions and the classrooms in the last quarter of the nineteenth century, remaining only a word occasionally encountered in casebooks" and concluding that natural law 
The transition from the era of natural law to an international law dominated exclusively by positive sources of law did not happen overnight. It was a gradual process and one cannot point to a single moment when the law turned its back on natural law. But within that period there are moments where the transition is more evident than in other moments. One case where the tension between the two paradigms is especially stark is The Antelope, a U.S. Supreme Court case from 1825.19 Perhaps no other case better exemplifies what was lost when international law shed its natural law origins. Because of this loss, the case also foreshadows what was to come after-natural law's covert re-importation into international law under the guise of jus cogens.

The Antelope was a slave ship that was off the coast of Florida in 1825, though at the time Florida was a territory of Spain and not yet a part of the United States. The ship's history was complex. ${ }^{20}$ Originally built in the United States, the ship was in the hands of a foreign owner and was engaged in the slave trade, specifically the transportation of slaves from Africa to Europe, pursuant to a license issued by the government of Spain, which at the time still recognized the legality of the slave "trade," which basically involved the kidnapping of Africans followed by their transportation and sale into slavery in either Europe or the United States.

The Antelope was captured by a privateer off the coast of Africa who again used the ship to transport slaves from Africa. The ship was placed under the captaincy of John Smith. ${ }^{21}$ But during its voyage, the Antelope was captured by officers of the U.S. Revenue Marine Service, which was a part of the U.S. Treasury Department. The ship was then brought by the authorities to port in the United States, at Savannah, Georgia, and the case concerned what would become of the 280 slaves on board the ship. There was uncertainty about the intended destination of the Antelope when it was under the control of the privateer. Ostensibly it was transporting slaves to Cuba, but there is some suggestion that it was actually transporting the slaves to the southern United States..$^{22}$ If so, this would have been illegal under federal law, since the United States had, by this time, banned the international slave trade (though not slavery itself). ${ }^{23}$ The

\footnotetext{
"survived only in the Catholic law schools, rather academic in nature and effectively ghettoed from the rest of the profession" at 473).

19 The Antelope, 23 US (10 Wheat) 66 (1825) [The Antelope].

20 See John T Noonan Jr, The Antelope: The Ordeal of the Recaptured Africans in the Administrations of James Monroe and John Quincy Adams (Berkeley: University of California Press, 1977).

21 Ibid at 51-52.

22 The Antelope, supra note 19 at 124.

23 At the time, slavery was illegal in all northern states under state law, but legal in southern states.
} 
transportation of slaves from Africa to the United States was designated a form of piracy under federal law. ${ }^{24}$

John Smith, the captain of the Antelope after it was captured by the privateers, argued that both the ships and its slaves were rightfully his because they were captured as a prize of war. ${ }^{25}$ In order to determine whether the ship could be considered a prize of war, subject to private capture, the U.S. Supreme Court had to determine whether the ship was engaged in unlawful activity in violation of international law. To determine this question, the Supreme Court was faced with a methodological quandary: should norms of international law be identified by looking to natural law or by custom? In the preceding century, reference to natural law was once common, but the court was hesitant to continue with that methodology. ${ }^{26}$ In the case of The Antelope, the determination of methodology was outcome-dependent. Nearly everyone in the case conceded that the slave trade-and slavery itself-violated principles of natural justice. To use human beings as property and to deny them basic rights is - and was-contrary to basic principles of humanity and universal reason. On the other hand, an inquiry into "positive" sources of international law would yield the opposite conclusion. Although several nation-states had, by this time, banned the slave trade under their domestic law, there was no binding international treaty prohibiting the slave trade on all states. ${ }^{27}$ Furthermore, while states such as the United Kingdom and the United States had criminalized the slave trade, others (such as Spain and Portugal) had not, and some were continuing the practice, thus negating a finding that international custom prohibited the practice. Justice Marshall thus concluded:

That it is contrary to the law of nature will scarcely be denied. That every man has a natural right to the fruits of his own labour, is generally admitted; and that no other person can rightfully deprive him of those fruits, and appropriate them against his will, seems to be the necessary result of this admission. But from the earliest times war

24 Federal law stated:

That if any person or persons whatsoever, shall, on the high seas, commit the crime of piracy, as defined by the law of nations, and such offender, or offenders, shall afterwards be brought into or found in the United States, every such offender or offenders shall, upon conviction thereof, before the circuit court of the United States for the district into which he or they may be brought, or in which he or they shall be found, be punished with death.

An Act to Protect the Commerce of the United States, and Punish the Crime of Piracy, c 77, 3 Stat 510, s 5 (1819).

25 The Antelope, supra note 19 at 68-69.

26 For example, in United States v La Jeune Eugenie, 26 F Cas 832 (D Mass 1822) at 837, an American court concluded that the slave trade violated the law of nations because "[a]ll cruelty, inhumanity, barbarity and oppression, are forbidden by the law of nature, everywhere."

27 The Antelope, supra note 19 at 104, 120. 
has existed, and war confers rights in which all have acquiesced. Among the most enlightened nations of antiquity, one of these was, that the victor might enslave the vanquished. This, which was the usage of all, could not be pronounced repugnant to the law of nations, which is certainly to be tried by the test of neral usage. That which has received the assent of all, must be the law of all. ${ }^{28}$

The answer here was clear. If states are practicing the slave trade, it cannot violate customary international law.

In The Antelope, the stakes of this transition became abundantly clear. Without natural law in the picture, there is nothing but positive law to determine the content of international law. Since state practice had not yet achieved the uniformity necessary to establish a new custom, the Supreme Court concluded that the slave trade was not a violation of international law. As a result, the captured slaves remained enslaved, rather than set free. Their freedom was denied.

The Antelope took place during a liminal period, after the decline of natural law, but before the dawn of jus cogens in its contemporary manifestation. ${ }^{29}$ In that liminal time period, international law was a dark affair. In some ways, the development of jus cogens generations later-i.e. that there some places that international law was not permitted to go, regardless of the positive sources-was a recognition that the status quo embodied in The Antelope was intolerable. But the commitment to legal positivism, and the rejection of natural law, made it genuinely uncertain how to rectify the gap between the positive sources of international law and any normative limits to the scope of international law. ${ }^{30}$ In a sense, international law was caught between apology and utopia. ${ }^{31}$ Natural law was unrealistically utopian and untethered from positive sources of law. But the opposite approach, legal positivism, required conceding that even slavery was legal under international law-an apologist position if ever there was one. As Martti Koskenniemi puts the point:

Ibid at $120-21$

29 It should be noted that I am not claiming that The Antelope is some historically significant turning point. Rather, the case is a compelling example that shows the consequences, arguably intolerable, of the switch from a natural law-based international law to a positivistic international law-before the advent of jus cogens in its modern form.

30 Some scholars have identified the 1920 adoption of the statute for the Permanent Court of International Justice (PCIJ) as a crucial moment when legal positivism won out over natural law sources. Article 38 of the PCIJ Statute included no reference to natural law and would later become article 38 of the ICJ Statute. See ICJ Statute, supra note 17. For a discussion, see Lauri Mälksoo, "Sources of International Law in the Nineteenth-Century European Tradition: Insights from Practice and Theory" in Besson \& Jean D'Aspremont, supra note 16, 146 at 154-55.

31 See generally Martti Koskenniemi, From Apology to Utopia: The Structure of International Legal Argument (Cambridge, UK: Cambridge University Press, 2006). 
Finally, jus cogens doctrine shows itself as a compromise. It accommodates a descending with an ascending perspective: peremptory norms bind irrespective of consent (indeed, this must be so if they purport to limit what one may consent to) but what those norms are is determined by consent.

But the reconciliation is only apparent. While naturalism and positivism, justice and consent, are combined in the definition, they will break separate in any attempt to oppose the jus cogens on a non-consenting State. For a State may argue that a norm cannot be opposed to it because it has never recognized it as jus cogens. To counter this, we must prefer either the consensualist or the non-consensualist strand in jus cogens. Either the State's subjective consent is necessary or then it is not. If it is necessary, then we lose the distinctiveness of jus cogens vis-a-vis ordinary custom, or treaty, altogether. Moreover, we seem to collapse into what seems like full apologism. If it is not, then we must accept jus cogens either as form of majority legislation or a natural morality. The former solution seems unacceptable because it violates sovereign equality, the latter because utopian in a system premised on the subjectivity of value. ${ }^{32}$

In other words, for jus cogens to operate at its most demanding and utopian level-which is why jus cogens exists-it needs to move beyond the positive sources of law, which are inevitably apologist, since they end up mirroring existing state behavior.

\section{The Positivization of Natural Law}

Over time, jus cogens became entrenched as an enduring component of the international legal landscape. When the term first came to prominence in international legal discourse, the category of jus cogens was closely associated with the post-World War II development of human rights law. Human rights lawyers at the time typically did not view jus cogens as a creature of natural law. However, the way that lawyers understand or view a concept is not always a reliable guide to its underlying conceptual structure. Indeed, as many scholars have recognized, natural law covertly survived in pockets of international law, although only once jus cogens came to be recognized as a legitimate category. ${ }^{33}$

33 For a discussion of this phenomenon, see Andrea Bianchi, "Human Rights and the Magic of Jus Cogens" (2008) 19:3 Eur J Intl L 491 (observing with regard to jus cogens that the decision to codify in the Vienna Convention "a normative category with an open-ended character, the content of which could become intelligible only by reference to some natural law postulates, was tantamount to dignifying the latter's otherwise uncertain foundation by granting it the status of positive law" at 492-93). See also O'Connell \& Day, supra note 16 (arguing that the Vienna Convention assigns to the ICJ the task of determining whether a treaty is void because it conflicts with natural law qua jus cogens at $575)$ 
This transition was solidified by the inclusion of the jus cogens category in the highly influential Restatement (Third) of Foreign Relations Law, which listed the following norms as jus cogens:

A state violates international law if, as a matter of state policy, it practices, encourages, or condones:

(a) genocide,

(b) slavery or slave trade,

(c) the murder or causing the disappearance of individuals,

(d) torture or other cruel, inhuman, or degrading treatment or punishment,

(e) prolonged arbitrary detention,

(f) systematic racial discrimination, or

(g) a consistent pattern of gross violations of internationally recognized human rights. ${ }^{34}$

Over the years, the list from the Restatement has been questioned and criticized, with some scholars arguing for an expansive approach to jus cogens, with others arguing for a more restrictive approach, even limiting the category to fundamental axioms such as pacta sunt servanda and eschewing the more substantive norms referenced in the Restatement. Indeed, one of the successes of jus cogens as a category is that it is an empty vessel waiting to be filled. Without clear criteria defining its content, international lawyers can strategically fill it with a rotating list of contested legal norms.

Stepping back from discrete controversies over its content, the more salient development is that jus cogens represented the positivization of natural law. ${ }^{35}$ It was the dressing of natural law in respectable clothes recognized by legal positivism, although the clothes were thin and revealing. ${ }^{36}$ To anyone who dared to look, the inner beauty of natural law was there for all to see. Had international lawyers argued that some treaties were invalid because they violated natural law, their statements would be met with blank stares. However, using the new concept of jus cogens, dressed in Latinate jargon, lawyers were capable of invoking a quasi-naturalist reading

34 Restatement (Third) of Foreign Relations Law $§ 702$ (1987) [Restatement of Foreign Relations Law].

35 See Bianchi, supra note 33 at 492 . Bianchi attributes the phrase "positivization" to RenéJean Dupuy. See United Nations Conference on the Law of Treaties, First Session Vienna, March 26-May 24 1968: Official Records, 1969, UN Doc A/CONF.39/11 at 258, para 74.

36 The Restatement recognizes in the comments section that jus cogens norms have "strong antecedents" in natural law. See Restatement of Foreign Relations Law, supra note 34 § $701, \mathrm{cmt} \mathrm{b}$. 
of international law without the full baggage that would have come with a more explicit invocation of the natural law of a prior era.

True, over the years, scholars have attempted to offer a coherent explanation for the rise of jus cogens in a way that situates it within the positive sources of law. ${ }^{37}$ While it clearly cannot be based on treaty law (because it purports to operate in a position hierarchically superior to treaties and nullify those that contravene jus cogens), the most plausible account of its legal status is that it constitutes a form of "super-custom". ${ }^{38}$ Under this view, norms ripen from custom to jus cogens when they achieve almost universal consensus. This view, when taken to its logical extreme, is meaningless, because the value of using a jus cogens norm is that it can be applied in situations of legal controversy, where unanimity is noticeably absent. This problem might be solved by loosening the requirement of near universality, so that the jus cogens label can be applied to contested norms just as long as they meet a higher standard of state practice and opinio juris than what is required to reach the status of customary international law. However, even with this problem resolved, there is a deeper problem. Customary international law is reversible, in the sense that a sufficient level of state practice and opinio juris could support the recognition of a counter-norm that is the opposite of the prior customary law. In contrast, a jus cogens norm cannot be unwound simply by virtue of widespread disrespect of the norm by a large number of states. Once the jus cogens norm is entrenched, it is here to stay, regardless of state practice. Indeed, there would be something odd about the idea that states could relieve themselves of the jus cogens obligation not to engage in genocide simply by getting a sufficient number of states to violate the norm. This fact stands in stark tension with the theory that jus cogens is a form of super-custom. If indeed jus cogens were built upon a foundation of customary international law, one could have expected it to be fully reversible in just the same way as customary international law. Since it is not reversible in this way, it is unlikely that jus cogens, at least in its current manifestation, can be explained by reference to custom as a positive source of law. ${ }^{39}$ The search for a bridge between jus cogens and legal positivism must continue.

37 See e.g. David F Klein, "A Theory for the Application of the Customary International Law of Human Rights by Domestic Courts" (1988) 13:2 Yale J Intl L 332 (referring to the argument "that there exists a subclass of customary international law, jus cogens, that has peremptory force and cannot be abrogated by domestic law or treaty" at 347).

38 Several scholars have used the phrase "super-custom" to refer to jus cogens, though with various meanings. See e.g. Stephens, supra note 2 at 250; W Michael Reisman, "Unilateral Action and the Transformations of the World Constitutive Process: The Special Problem of Humanitarian Intervention" (2000) 11:1 Eur J Intl L 3 at 15, n 29; Shaina Stahl, "Unprotected Ground: The Plight of Vanishing Island Nations" (2010) 23:1 NY Intl L Rev 1 at 18.

39 See Pellet, supra note 17 at 766-67. 
The other possibility is that jus cogens flows from general principles of law, although that fails to fit with the doctrine, nor does it explain how it could be non-derogable. Article 38 of the ICJ Statute recognizes as a valid source of the law "the general principles of law recognized by civilized nations," but neither defines them nor provides a methodology for determining what counts as a general principle. Generally speaking, international lawyers have counted as general principles various commonalities or background norms that form the basic architecture of domestic legal systems. ${ }^{40}$ These principles are often constitutive of the rule of law and many times have a procedural component. However, jus cogens norms are often substantive, such as the prohibition against torture or the prohibition against genocide. ${ }^{41}$ Some of these prohibitions achieved jus cogens status at the international level before they were widely recognized in all domestic legal systems. Indeed, in the case of torture and genocide, these crimes were subsequently penalized in many states as a way of fulfilling their international obligation to criminalize the conduct in their domestic legal systems. ${ }^{42}$ In other words, the prohibition was recognized at the international level first, then secondarily mirrored in domestic legal systems. If jus cogens were built on general principles of law, then one would expect the exact opposite: the norm would be firmly entrenched at the domestic level first before obtaining jus cogens status at the international level. Finally, jus cogens norms are non-derogable, and there is nothing in the notion of general principles of law that suggests that they are inherently non-derogable. Indeed, the whole value of jus cogens, as a distinct category, is that it is non-derogable, and it seems unlikely that the sine qua non aspect of that category flows from general principles, which do not have that quality.

It would seem, then, that the best and most compelling answer is that jus cogens is natural law in positive clothing. ${ }^{43}$ Although international lawyers today are inclined to resist this uncomfortable conclusion, the failure to integrate jus cogens convincingly into the positive sources of international law makes this conclusion irresistible. Of course, the fact that jus cogens contains some residual naturalism does not entail, by definition, the re-emergence of natural law per se as it was understood in the time of

40 See Mälksoo, supra note 30 at 157.

41 See David S Mitchell, "The Prohibition of Rape in International Humanitarian Law as a Norm of Jus Cogens: Clarifying the Doctrine" (2005) 15:2 Duke J Comp \& Intl L 219 (identifying as jus cogens norms "genocide, crimes against humanity, war crimes, torture, aggression, piracy, and slavery" at 232).

42 In the case of torture, the obligation to criminalize comes from articles 4-7 of the Convention Against Torture. See Convention Against Torture and Other Cruel, Inhuman or Degrading Treatment or Punishment, 10 December 1984, 1465 UNTS arts 4-7 (entered into force 26 June 1987). See also Aditi Bagchi, "Intention, Torture, and the Concept of State Crime" (2009) 114:1 Penn St L Rev 1.

43 See O'Connell \& Day, supra note 16 (asserting that the modern concept of jus cogens is best explained by natural law rather than positivism at 563). 
Grotius and other leading natural lawyers. Indeed, as the following Part will demonstrate, today's natural law-and its theory-is far more advanced that its historical progenitor. Moreover, natural law today neither occupies the field nor casts the long shadow that it once did. However, the notion of jus cogens as an ethical minimum suggests that mixed in with the positive sources of international law, there is a residual-perhaps even faint-naturalism that cannot be exorcised entirely from the body of international law. To help make this point, the following Part analyzes one leading, contemporary theory of jus cogens and argues that it is best understood with reference to that residual naturalism.

\section{The Fiduciary Theory of Jus Cogens}

In their joint work on the fiduciary theory, Criddle and Fox-Decent have provided a theoretical account of jus cogens. ${ }^{44}$ As noted above, Criddle and Fox-Decent suggest that states stand in a fiduciary relationship with not only their own citizens but also, simultaneously with humanity at large, thus requiring the state to exercises its sovereign authority not only in the interests of its own people but also in the interests of the world community. ${ }^{45}$ While the former obligation explains why a state must treat its own citizens humanely, the latter fiduciary obligation provides the foundation for an account of jus cogens because it requires that sovereigns exercise their authority in a way that is consistent with the interests of members of the world community. As Criddle and Fox-Decent explain:

[I]nternational law's power-conferring fiduciary norm authorizes the state to secure legal order, but subject to fiduciary constraints that include human rights and jus cogens. Under this theory, the state's sovereignty to govern domestically and represent its people internationally consists in its fiduciary obligation to do so. And because this authorization is constrained and constituted by a duty to respect jus cogens and human rights, state sovereignty is likewise constrained and constituted. ${ }^{46}$

44 Although Criddle and Fox-Decent distinguish their approach from a variety of prior efforts, including natural law theories, I believe it is best to view the fiduciary theory as a form of neo-natural law theory, at least if it is presented as embodying legal, as opposed to moral, requirements. One could have presented the fiduciary theory as purely aspirational, i.e. as a moral theory about the future of international law, but they conclude that human rights are

legal rights correlative to the state's fiduciary (and therefore legal) duty to establish legal order on behalf of those people. A state that fails to respect human rights transgresses international law's fiduciary authorization of state sovereignty, an authorization that flows from the fiduciary principle, which is itself a principle of legality.

Criddle \& Fox-Decent, Fiduciaries of Humanity, supra note 3, at 107 [emphasis added].

$45 \quad$ Ibid at 42.

$46 \quad$ Ibid at 95. 
These fiduciary relationships involve an implicit bargain: the prerogatives of sovereignty are tendered in exchange for the state's promise to fulfill its obligations in that fiduciary relationship. It must govern for the benefit of its people in order to fulfill its internal fiduciary obligations, and it must also act in ways that respect the interest of outsiders as well in order to fulfill its external fiduciary obligations (to humanity writ large). ${ }^{47}$

The fiduciary theory helps explain why there is - and ought to be-a corner of international law that is not based on consent. Regardless of what commitments a state voluntarily accepts through negotiated agreements, each state is bound to its fiduciary obligations, simply by virtue of the conditions attached to the sovereignty conferred on it by the international community. One could, if one wished, couch this as a form of tacit consent: the state implicitly consents to these legal restrictions in exchange for accepting the "benefits" of sovereignty conferred by the international community. Although Fox-Decent and Criddle do not use a "tacit consent" structure, this dispute is largely intramural.48 The key element of their edifice is the fiduciary obligation that runs both internally and externally and therefore outstrips the obligations that positive international law imposes on each state's relations with other sovereign states. The fiduciary model explains that the state-to-state obligations of positive law often obscure a deeper set of normative commitments that run between a state and its people and between a state and humanity. As Fox-Decent and Criddle note, the concept of jus cogens therefore establishes the ethically minimum content of international law (borrowing a well-chosen phrase cut from Verdross). ${ }^{49}$

In their earlier work together, Fox-Decent and Criddle do not describe their theory as naturalist. In fact, they explicitly state that:

The fiduciary view also moves beyond natural law accounts of jus cogens which depend on vague notions of "the international conscience" or a "superior order of legal norms." While the fiduciary theory, as we shall see, relies explicitly on a moral idea of dignity, its reliance is not on dignity in the abstract, but on the legal significance of dignity within the juridically secure confines of a full-blooded legal relationship — the state-subject fiduciary relationship. Jus cogens norms flow from this relationship, and thereby embody distinctive norms that structure the very relationship that is constitutive of state sovereignty. Thus, the fiduciary model promises to reconcile jus

47 Ibid.

48 See e.g. Evan Fox-Decent, Sovereignty's Promise: The State as Fiduciary (Oxford: Oxford University Press, 2011) at 117-19.

49 See Alfred von Verdross, "Forbidden Treaties in International Law: Comments on Professor Garner's Report on 'The Law of Treaties”' (1937) 31:4 Am J Intl L 571. 
cogens with sovereignty, and through a principled legal framework that helps to illuminate the nature of both. ${ }^{50}$

If the fiduciary theory does not rely on "vague" notions such as the international conscience, what does it rely on? According to Criddle and FoxDecent, jus cogens norms are "constitutive" of sovereignty-a description that could be applied to the fiduciary theory overall. ${ }^{51}$ The entirety of the fiduciary theory is an exercise in teasing out the implications of the concept of sovereignty - the prerogatives of sovereignty presuppose a relationship between governor and governed that constitutes a fiduciary relationship that imposes obligations on the sovereign. Although the content of the fiduciary account strays from the specifics of the theories that might have been offered by the leading theoreticians of the natural law era, the structural similarities are similar: the fiduciary theory provides an account of international law that goes well beyond the four corners of positivism.

At this point, one might object that the fiduciary theory is "analytic" or "interpretive", in the sense that its goal is to explain the structure of the existing system of international law. ${ }^{52}$ If the fiduciary theory were limited to this exercise - to excavating the deep grammar of international lawthen one might conclude that such a purely interpretive theory is merely operating at a different level of abstraction and in that way not inconsistent with the requirements of legal positivism. That being said, the fiduciary theory is not entirely interpretive; it is also normative, a fact which is on full display in its account of jus cogens. ${ }^{53}$ Not only does the fiduciary theory provide a justification for the existence of jus cogens as a category of law that extends beyond the positive sources of law, but it also purports to establish criteria for identifying the particular norms of jus cogens. ${ }^{54}$ In that exercise, its results extend beyond merely explaining the current state of the law and instead posit the normatively correct answers that the system

50 See Evan J Criddle \& Evan Fox-Decent, "A Fiduciary Theory of Jus Cogens" (2009) 34:2 Yale J Intl L 331 at 348 [footnotes omitted] [Criddle \& Fox-Decent, "Fiduciary Theory"].

51

52

53 model is that the whole of Article 53 of the VCLT is superfluous. States are bound by jus cogens whether they have ratified the VCLT or not and irrespective of whether Article 53 has the status of customary international law." Criddle \& Fox-Decent, "Fiduciary Theory", supra note 50 at 355.

54 See Criddle \& Fox-Decent, Fiduciaries of Humanity, supra note 3 at 79:

As an interpretive theory, the fiduciary model explains the presence and juridical character of the norms that lie at the core of IHRL and jus cogens respectively. As a prescriptive theory, the fiduciary model supplies valuable guidelines for distinguishing peremptory human rights from others that are appropriately subject to limitation or derogation. 
ought to recognize if only international lawyers and other actors recognized the veracity of the fiduciary theory.

Given that the fiduciary theory strays from a strict adherence to legal positivism, it is unclear how it should be classified. One could describe the theory as "anti-positivist" or "post-positivist"-labels that accurately convey the degree to which the fiduciary moves beyond a strictly positivist approach to international law. Anti-positivism is most associated with discussions of the work of Lon Fuller and Ronald Dworkin, ${ }^{55}$ although the term post-positivism might also convey the degree to which the fiduciary theory moves beyond a narrow understanding of legal positivism.

The fiduciary theory could be consistent with "inclusive" legal positivism, the view that the law is mostly but not wholly determined by positive sources. ${ }^{56}$ Under this inclusive view, the content of the law might also be provided, in part, by extra-positive sources—such as morality— that might be helpful in interpreting or cashing out the scope of the positive sources. ${ }^{57}$ In other words, the content of the law is dominated by positive sources, but the positive sources are not the exclusive avenue through which to find the content of the law, and reference to moral considerations play an important role in how legal actors identify the content of legal norms.

The point of inclusive legal positivism (or at least some versions of it), is that the positive sources do not fully exhaust the content of legal norms. The fiduciary theory provides an account of the content of jus cogens that makes reference to interpretive methodologies that extend beyond the positive sources of law: treaties, custom, and general principles of domestic law. To "find" the content of jus cogens, according to Criddle and Fox-Decent, there is no substitute for going through the interpretive exercise described in the fiduciary theory and to ask whether certain norms are implicit in the notion of sovereignty. ${ }^{58}$ Though that exercise is far more subtle-and convincing - than what Grotius or others in the natural law era offered by way of answers, there is no denying that this interpretive exercise is not, by itself, a positive source of law.

In a sense, it does not matter what one calls this interpretive exercise. It could be naturalism, neo-naturalism, crypto-naturalism, or just the dark

55 See generally Robert S Summers, Lon L Fuller (London, UK: Edward Arnold, 1984).

For a good explanation of the difference between inclusive legal positivism and other forms of positivism, see Jules L Coleman, "The Architecture of Jurisprudence" (2011) 121:1 Yale LJ 2 (arguing that "inclusive legal positivism rejects the idea that normative or moral facts cannot contribute to the law's content" at 54).

57 Ibid.

58 See Criddle \& Fox-Decent, "Fiduciary Theory", supra note 50 (explaining that the "fiduciary theory thus invites the international community to employ its analytical framework as the foundation for a new international consensus, but without mistaking the intended consensus for the normative basis of jus cogens" at 377). 
hole of normativity that exerts a gravitational pull once the positive sources of law have run out. ${ }^{99} \mathrm{My}$ view is that anything that goes beyond positivism has some element of naturalism in it, because the theory flows either directly or indirectly from reason, rather than from the positive sources of law. ${ }^{60}$ In the case of the fiduciary theory, the content of jus cogens flows from "the specific content of ... the fiduciary obligation of the state to secure the legal order," 61 and moreover "the formal criteria of jus cogens ... are desiderata from the internal morality that Fuller thought legislation should aspire to achieve." 62 According to the fiduciary theory, there are also substantive criteria for jus cogens, including: integrity, fairness, reasonableness, fundamental equal security, and finally, "a procedural principle regarding the rule of law: a norm will count as jus cogens if respect for it is indispensable to the state's ability to secure legality for the benefit of all."63 Where do these procedural and substantive criteria come from? Not from the positive sources, but rather from the principles embodied in the concept of sovereignty and the fiduciary relationship implicit in the sovereignty "bargain", as one might call it. Once something flows from beyond positive sources of law and requires theoretical elaboration to identify the content of that norm, the very same objections that one hears about natural law will apply, mutatis mutandis, to that newer theoretical construct, regardless of how satisfying that theoretical construct may be. The fact that the theoretical construct is no longer called natural law is more a function of historical pedigree than it is a function of the structure of the theory.

Consequently, if one wants to defend the fiduciary theory of international law, and in particular the fiduciary theory of jus cogens, then one is

59 Similarly, see O'Connell \& Day, supra note 16 (concluding that "the realm of [natural law] is that which positivism does not explain" at 579).

60 There are other international lawyers who recognize a role for extra-positive thinking. See e.g. Antônio Augusto Cançado Trindade, International Law for Humankind: Towards a New Jus Gentium, 2nd ed (Leiden: Martinus Nijhoff, 2013). Also, some individual opinions at the ICJ have referenced natural law. For example, consider the dissenting opinion of Judge Tanaka, who concluded that:

[I] $\mathrm{t}$ is undeniable that in Article 38, paragraph 1(c), some natural law elements are inherent. It extends the concept of the source of international law beyond the limit of legal positivism according to which, the States being bound only by their own will, international law is nothing but the law of the consent and auto-limitation of the State."

South West Africa Cases (Ethiopia v South Africa; Liberia v South Africa), [1966] ICJ Rep 6 at 298.

61 See Criddle \& Fox-Decent, "Fiduciary Theory", supra note 50 at 365 [emphasis in original].

62 Ibid at 366.

63 Ibid at 367 [emphasis in original]. 
required to defend some role for naturalism in international law. ${ }^{64}$ The fate of the two are inextricably linked. If naturalism has no legitimate place whatsoever in international law, then I see no way to vindicate the fiduciary theory of jus cogens. If the fiduciary theory is correct, jus cogens is not just a function of natural law, it is a function of a very particular flavor of natural law theory: a fiduciary model that grounds ultimate legitimacy in the world's peoples_-both individually as constituents of particular states but also collectively as the embodiment of humanity itself.

In this essay, I have asserted that international lawyers have failed to appreciate the inherent naturalism of jus cogens. Adopting the fiduciary theory may help international lawyers to finally come to terms with its inherent naturalism, though it would help if the proponents of the fiduciary theory would themselves wear their naturalism on their sleeves, transforming what would otherwise be a crypto-naturalism to an unapologetic neo-naturalism that finally makes naturalism respectable again for the modern international lawyer.

\section{The Value of Obfuscation}

Although I support the theoretical exercise of providing a conceptually clear foundation for jus cogens, transparency comes, ironically, with high costs. What made jus cogens so successful as a legal category was its ambiguity and its slippery ability to resist being pinned to a particular source of positive law. ${ }^{65}$ The positive nature of jus cogens was a useful fiction without which the category would not exist. 66 The positive fiction allowed international lawyers to accept natural law under the guise of positive sources of law. ${ }^{67}$

To make this point more sharply, we could engage in an exercise of counterfactual history. Imagine a world where the natural law origins of jus cogens were firmly and transparently communicated to the entire

64 On this point, see O'Connell \& Day, supra note 16 (arguing that jus cogens norms such as the prohibitions against aggression, torture, genocide, etc. "are all fundamentally moral principles" at 578).

65 For a discussion, see Anthony D’Amato, "It's a Bird, It's a Plane, It's Jus Cogens!" (1990) 6:1 Conn J Intl L 1 (1990).

66 A few other legal scholars have argued that conceptual confusion was a necessary precondition for the advancement of jus cogens. See e.g. Jean d'Aspremont, "Jus Cogens as a Social Construct Without Pedigree" (2015) 46 Netherlands YB Intl L 85 (the "foundational nonchalance is made possible by virtue of a whole series of conceptual constructions that set the question of the pedigree of the jus cogens mechanism aside" at 89).

67 But see Criddle and Fox-Decent, "Fiduciary Theory", supra note 50 at 347, who disagree: "[W] hile the jus cogens concept has achieved widespread acceptance across the international community, its unsettled theoretical foundation has impeded its implementation and development." If my account is correct, its unsettled foundation had the opposite consequence: it allowed the concept to flourish. 
world. If you will, imagine that Fiduciaries of Humanity had been published 75 years ago, just as the human rights revolution was on the horizon. Also, imagine then that international lawyers were convinced by its argument and understood that jus cogens embodied an ethical minimum flowing from the fiduciary relationship between a state and its people and between a state and humanity. What would have happened?

To me, the answer is plain. In that alternative universe, jus cogens would have been disregarded as a "mere" philosophical or moral concept, undeserving of the lofty label "law". To prove the point with a more contemporary example, consider the debate over the dilemma of humanitarian intervention, and the NATO military action against Serbia specifically. ${ }^{6}$ Although there are disagreements to be sure, the vast majority of international lawyers came to view the intervention as illegal. ${ }^{69}$ Arguments in favor of the intervention were dismissed as extra-legal, i.e. as sounding in philosophy, morality, or politics. ${ }^{70}$ The assumption underlying these epithets was to protect the autonomy of law from other disciplines and to deny the label of "law" to anything that did not hew closely to the traditional sources of positive law.

In the same way, had jus cogens been understood to be natural law incarnate, or even a form of residual naturalism, it never would have had the impact that it did. Moreover, I submit that the entire human rights revolution-which depended on the existence of jus cogens as an ethical minimum unmoored from state consent-would never have occurred either, or at the very least, not in the same way. A fully rendered natural law jus cogens would have been rejected immediately as insufficiently law-like, as a concept that had wandered across the university from the philosophy department to the law faculty, where it was marooned, lost, until it could be sent back to its home country like a repatriated refugee-concept. The result would have been a lost opportunity for international law-a win for international legal theory in general but a firm loss for human rights lawyers.

It may seem strange to argue for obfuscation, but in some cases, obfuscation serves a decidedly pragmatic purpose. It papers over the inner-

68 For a discussion of these issues, see generally Antonio Cassese, "Ex Inuria Ius Oritur: Are We Moving Towards International Legitimation of Forcible Humanitarian Countermeasures in the World Community?" (1999) 10:1 Eur J Intl L 23; Antonio Cassese, "A Follow-Up: Forcible Humanitarian Countermeasures and Opinio Necessitatis" (1999) 10:4 Eur J Intl L 791.

69 See Harold Hongju Koh, "Humanitarian Intervention: Time for Better Law" (2017) 111 AJIL Unbound 287 (arguing that humanitarian intervention is not always illegal but conceding that a "majority of international law scholars still probably ... share the belief that unilateral humanitarian intervention is always illegal" at 287).

70 For a discussion of the moral arguments for humanitarian intervention, see R George Wright, "A Contemporary Theory of Humanitarian Intervention" (1989) 4:3 Fla Intl LJ 435 at $445 \mathrm{ff}$. 
workings that lawyers would rather ignore because if they saw them they would not like what they see. Does this obfuscation need to continue forever? Even now, with jus cogens firmly entrenched, some international lawyers might reflexively reject the natural law approach to jus cogens. For these diehard positivists, having understood jus cogens as fundamentally naturalistic, they might turn around and reject jus cogens as the fruit of a poisonous tree. Indeed, that is the strength of legal positivism's magnetic pull. Rather than accept the natural law origins of jus cogens, some would abandon the concept altogether. For that reason, we might be tempted to continue the obfuscation in order to preserve the place of jus cogens in our future legal architecture. Indeed, one might worry that the mere publication of this account, and the general recognition that jus cogens is inconsistent with a theory of the positive sources of international law, will cause jus cogens to lose a bit of its luster to practicing international lawyers who are preternaturally inclined to support positivism. If so, perhaps this article should never have been written; it should be forgotten so that jus cogens may persist untainted by naturalism's seemingly flawed legacy.

However, the obfuscation need not last forever. Legal concepts are at their most vulnerable at their inception; once they have become established, however, they become sticky, and the negative consequences associated with a concept might be enough to prevent the concept from getting off the ground but not enough to dislodge the concept from the current toolbox of international lawyers. Although this represents a bias in favor of current categories over proposed categories, it is undeniably true that proposed categories undergo a scrutiny that pre-existing categories must never endure. Jus cogens is here to stay, and even its latent naturalism will likely not cause lawyers to abandon the concept. For this reason, the psychological account of international lawyers that I have offered here is entirely backward-looking, focused on the calculations that early adopters faced with they were confronted with a new and uncertain legal concept. But my account does not suggest a forward-looking vulnerability in the façade of jus cogens that would crack if international lawyers understood its naturalism. The concept is here to stay no matter what. We can publicize the residual naturalism of the fiduciary theory with a clear conscience without fear that it will do drastic damage to the structure of public international law.

One might argue that the lack of a transparent ground for jus cogens has prevented international law from articulating clear criteria for which legal norms are entitled to non-derogable status..$^{71}$ Perhaps, if a fiduciary

71 See Eva M Kornicker Uhlmann, "State Community Interests, Jus Cogens and Protection of the Global Environment: Developing Criteria for Peremptory Norms" (1998) 11:1 Geo Intl Envtl L Rev 101 (concluding that "[i]dentifying criteria for jus cogens norms is not simply a valuable, but rather a necessary exercise" and predicting that "[w]ithout a 
theory of jus cogens, or some other natural law theory, were widely accepted, the international legal community could at least have ground rules for debating the inclusion or exclusion of particular norms from the holy status of jus cogens. As noted above, the fiduciary theory articulates formal and substantive criteria for jus cogens, which leads Criddle and Fox-Decent to conclude, for example, that the prohibition against torture and genocide are jus cogens but that the prohibition against piracy is not. ${ }^{72}$ The formal criteria flow from Lon Fuller's account of the "internal morality" of law, while the substantive criteria (such as reasonableness and fairness) flow from the specifics of the fiduciary theory. ${ }^{73}$ This exercise in legal theory arguably provides the content to jus cogens that was missing for so many years.

In this regard, it is interesting to ask whether the success of jus cogens in practice requires this level of theoretical coherence, or whether theoretical coherence improves actual consensus on the ground among practicing lawyers. ${ }^{74}$ To consider this point, the provisions regarding jus cogens in the Restatement Third are instructive. The Restatement includes a list of jus cogens norms but refuses - even in the commentary - to articulate a particular theory of jus cogens. ${ }^{75}$ The result of this punting is that no one knew why those particular norms made the list, and no one could have a coherent conversation about which norms might be added to the list in the future. The rules of the game became inscrutable. The fiduciary theory, if widely accepted, would promise to change that, i.e. to articulate rules of the game that might allow a common discourse about jus cogens to gain traction. The real benefit of the fiduciary theory is that it purports to offer criteria to identify the non-derogable norms of international law. This could change our evaluation of the parallel universe described above. In a world where a fiduciary theory of jus cogens were widely accepted from the beginning, jus cogens as an idea might not have become as entrenched in international legal doctrine as it did, but at least clear criteria for its content would have been accepted among the few lawyers who were not scared off by its naturalism.

This counterfactual exercise suggests the answer to our question. Before we worry about a concept's intricate workings, and its content, we must

consensus on a set of criteria, jus cogens will remain an interesting theoretical, but practically inapplicable, concept” at 101 [emphasis in original]).

72 See Criddle and Fox-Decent, "Fiduciary Theory", supra note 50 at 376.

73 Ibid at 360-80.

74 See Markus Petsche, "Jus Cogens as a Vision of the International Legal Order" (2010) 29:2 Penn State Intl L Rev 233 (suggesting that "[d]isagreement on whether, and the extent to which, jus cogens is based on natural law, positivist or public order approaches continues to compromise not only a basic understanding of this doctrine, but also its coherent application in practice" at 246).

75 See Restatement of Foreign Relations Law, supra note 34 § 701-02. 
first have a concept to work with. In the parallel universe above, there would be little reason to clarify the inner workings of a concept that had failed to achieve widespread recognition. There is an order of battle that cannot be escaped. First, the concept must achieve widespread acceptance. Second, the concept can be used in particular ways. True, we might change the concept to make it more useful but doing so would have prevented the concept from achieving widespread acceptance in the first place. And a concept of jus cogens that few accept turns out to be not very useful at all. Another way of putting the point is that the lack of clarity surrounding jus cogens was a price to be paid; it was the cost of having the concept in the first place. But now that the concept of jus cogens is firmly entrenched in legal practice and unlikely to disappear, we can circle back, reveal its latent naturalism, and start the hard work of constructing doctrinal criteria for it. At least as far as jus cogens is concerned, the fiduciary theory arrived on the scene at precisely the right time.

\section{Conclusion}

There is no reason to lumber in collective ignorance forever. One possibility is to follow Criddle and Fox-Decent and get international lawyers to appreciate the philosophical and ethical foundations of international law generally and jus cogens specifically. This Essay has been a dialogical exercise in support of that goal. This Essay has been a dialogical exercise in support of that goal and suggests future lines of research: more analysis of the residual naturalism in jus cogens and a consideration of competing theories of naturalism that might be alternatives to the fiduciary theory. Although much of that work has already been done by Fox-Decent and Criddle, and other theorists working within the fiduciary framework, it would be worthwhile to evaluate those competing theories with specific reference to their latent naturalism, i.e. to do for them what I have done here for the fiduciary theory.

There is, however, a third option, which is far more radical: the return of the stealth approach. One could keep the legal theory but continue to dress it in positive clothes. Ironically, this might advance the goal of naturalism better than a transparent invocation of natural law. The result would be a form of acoustic separation: leave natural law for the philosophers and legal theorists and allow lawyers to continue with the legal fiction that jus cogens has some-unarticulated-basis in positive law. With that modus vivendi, natural law might continue to flourish but without any glory. If this is true, one might wonder whether the fiduciary theory should guide the application of legal doctrine, or whether it should remain in the background as theoretical foundation. While the current intellectual fashion is to produce theories that have doctrinal consequences, it need not be so. At issue in this debate is a fundamental assumption about the appropriate role of legal theory within contemporary international legal 
discourse. My own view is that legal theory has an appropriate role to play in international law and that theory and doctrine are inextricably linked. So, my own view is that the stealth approach is unnecessary and ought to be rejected. The goal of this Essay has been to show that profound confusion over the concept of jus cogens had some positive benefits during the origination period but that the confusion is now slowly lifting, revealing a crypto-naturalism in legal theory that might one day shed its crypto-status. 